\title{
Implementation of European Resuscitation Council guidelines: measurement of core body temperature in Emergency Medical Services in Europe
}

\section{Implementacja wytycznych Europejskiej Rady Resuscytacji - pomiar temperatury głębokiej w zespołach ratownictwa medycznego w Europie}

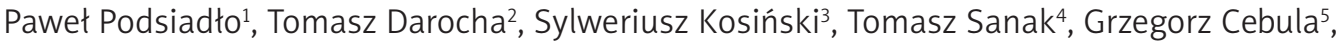 \\ Robert Gałązkowski ${ }^{6}$ \\ 1Department of Emergency Medicine, Jan Kochanowski University, Kielce, Poland \\ Head of the Department: Prof. Siarhei Panko MD, PhD \\ 2Department of Anaesthesiology and Intensive Care, Medical University of Silesia, Katowice, Poland \\ Head of the Department: Prof. Ewa Kucewicz-Czech MD, PhD \\ ${ }^{3}$ Faculty of Health Sciences, Jagiellonian University Medical College, Krakow, Poland \\ Head of the Faculty: Prof. Tomasz Brzostek MD, PhD \\ ${ }^{4}$ Department of Disaster Medicine and Emergency Care, Jagiellonian University Medical College, Krakow, Poland \\ Head of the Department: Arkadiusz Trzos MD, PhD \\ ${ }^{5}$ Department of Medical Education, Jagiellonian University Medical College, Krakow, Poland \\ Head of the Department: Grzegorz Cebula MD, PhD \\ ${ }^{6}$ Department of Emergency Medical Services, Medical University of Warsaw, Warsaw, Poland \\ Head of the Department: Prof. MUW Robert Gałązkowski PhD
}

Medical Studies/Studia Medyczne 2020; 36 (1): 14-17 DOI: https://doi.org/10.5114/ms.2020.94083

Key words: hyperthermia, hypothermia, cardiac arrest, core temperature, emergency medical service.

Słowa kluczowe: hipertermia, hipotermia, zatrzymanie krążenia, temperatura głęboka, ratownictwo medyczne.

\begin{abstract}
Introduction: Precise assessment of core body temperature is required for the optimal treatment of hypothermic patients according to European Resuscitation Council (ERC) guidelines. Core temperature is the cut-off criterion for some crucial therapeutic decisions in the treatment of severe hypothermia. Because the medical equipment is expensive, it is likely that pre-hospital services are equipped according to the minimal legal requirements.

Aim of the research: To identify the legal provisions for suitable equipment and staff eligibility for core temperature measurement in European emergency medical services.

Material and methods: The questionnaires that consisted of two questions pertaining to legal regulations were distributed among Ministries of Health and ERC representatives in every country of the European Union.

Results: Eighteen out of 28 countries returned completed questionnaires. None of the analysed countries have official legal requirements regarding ambulance equipment with thermometers suitable for measuring core temperature. Most of the analysed countries have no legal provisions pertaining to the eligibility of medical staff to measure core temperature in ambulances.

Conclusions: Official regulations in European countries do not require emergency medical services to be equipped with thermometers suitable for measuring core temperature. Medical staff eligibility in this field has not been established in most countries. This may limit the possibilities for pre-hospital management of hypothermic patients according to ERC guidelines.
\end{abstract}

\section{Streszczenie}

Wprowadzenie: Prawidłowe posteppowanie z pacjentem w hipotermii opisane w wytycznych Europejskiej Rady Resuscytacji (ERC) wymaga dokładnego pomiaru temperatury głębokiej ciała. Zgodnie z tymi wytycznymi temperatura głęboka jest punktem odcięcia dla szeregu kluczowych decyzji terapeutycznych, takich jak wstrzymanie podawania leków lub ograniczenie liczby prób defibrylacji elektrycznej. Również decyzja o transporcie pacjenta do ośrodka, który posiada ogrzewanie pozaustrojowe, ściśle zależy od temperatury. Ze względu na koszty sprzętu medycznego można się spodziewać, że służby ratownicze otrzymują wyposażenie na minimalnym poziomie wymaganym przez przepisy prawa.

Cel pracy: Ocena uregulowań prawnych dotyczących wyposażenia ambulansów i uprawnień personelu medycznego w zakresie pomiaru temperatury głębokiej na etapie przedszpitalnym w krajach Unii Europejskiej. 
Materiał i metody: Przeprowadzono badanie ankietowe. Ankietą objęto ministerstwa zdrowia oraz lokalne przedstawicielstwa ERC we wszystkich krajach Unii Europejskiej.

Wyniki: Odpowiedzi uzyskano z 18 spośród 28 krajów. W żadnym z państw nie ma oficjalnych wymagań dotyczących wyposażenia ambulansów w termometry przystosowane do pomiaru temperatury głębokiej. Większość krajów nie zdefiniowała uprawnień personelu medycznego do takiego pomiaru w okresie przedszpitalnym.

Wnioski: Służby ratownictwa medycznego w Europie nie są zobowiązane prawnie do wyposażenia swych zespołów w termometry przystosowane do pomiaru temperatury głębokiej ciała. Możliwości pełnej realizacji zaleceń ERC i prowadzenia optymalnego leczenia chorych w hipotermii głębokiej na etapie przedszpitalnym mogą być z tego powodu ograniczone.

\section{Introduction}

Reversible causes of cardiac arrest should be excluded in the pre-hospital period in order to increase a patient's chances of survival [1]. Although severe hypothermia is associated with refractory cardiac arrest, it can be successfully treated with a good neurological outcome $[2,3]$. Core temperature (Tc) is the cut-off criterion for some crucial therapeutic decisions in the treatment of severe hypothermia indicated by ERC guidelines since the 2005 edition. The term "core temperature" appears in ERC guidelines 2015 at least 50 times, and not just in the section dedicated to the treatment of accidental hypothermia. According to the ERC 2015 guidelines, Extracorporeal Life Support (ECLS) is the treatment of choice for arrested patients with $\mathrm{Tc} \leq 28^{\circ} \mathrm{C}$. In arrested patients with $\mathrm{Tc}<30^{\circ} \mathrm{C}$ defibrillation should be limited to three attempts and cardiopulmonary resuscitation (CPR) drug administration should be withheld, while at $\geq 30^{\circ} \mathrm{C}$ intervals between drug injections should be extended [4]. Hence, precise measurement of core temperature is required in order to follow the ERC guidelines. Currently, there is a lack of data on the conformity of national and local procedures for core temperature measurement.

\section{Aim of the research}

The aim of this study was to identify official requirements for equipment and medical staff eligibility for Tc measurement in European emergency medical services.

\section{Material and methods}

The survey was distributed in 28 European Union (EU) countries, with a questionnaire consisting of two questions, namely:

1. Are there, in your country, any legal provisions that enable emergency medical teams to measure a patient's core body temperature in the prehospital care system? If so, which member of the ambulance team is allowed to measure core temperature in the oesophagus or rectum? (multiple choice option) - doctor/paramedic (ALS-level)/nurse/other (please specify).

2 . Are there, in your country, any legal requirements (or requirements of national medical associations) to equip medical emergency teams with thermometers suitable for measuring core body temperature in prehospital settings (in the oesophagus or rectum)?
Two distribution channels were used. The Department of International Collaboration of the Polish Ministry of Health sent the form to its counterparts in all EU countries. In parallel, the Polish representative of the ERC, using the ERC Research Network, distributed the questions to all National Resuscitation Councils in the EU.

\section{Results}

A total of 18 countries (out of 28) returned their answers - Belgium, Croatia, Czech Republic, Denmark, Estonia, Germany, Ireland, Italy, Latvia, Lithuania, Luxembourg, Malta, the Netherlands, Poland, Romania, Slovenia, Sweden, and the United Kingdom. Nine countries responded through ministerial channels and 11 through ERC representatives (two countries through both ways). The overall response rate was $64.3 \%$ (18/28 countries). There were two incomplete or unclear answers - one for question 1 and two for question 2 . These answers were excluded from analysis. None of the analysed countries declared having official requirements for ambulance equipment to include oesophageal or rectal thermometers. In two countries out of $17(11.8 \%)$ physicians only are allowed to measure Tc. Paramedics and nurses are allowed to measure Tc in $23.5 \%$ and $29.4 \%$ of these countries, respectively, while $58.8 \%$ have no legal provisions in this matter.

\section{Discussion}

Althoug the guidelines of the ERC have required precise assessment of core body temperature since 2005 , emergency medical services in the EU have no legal background to be equipped with suitable thermometers. Moreover, in half of the countries analysed, the competences of medical personnel in this matter are not legally defined.

Because there is no legal provision to equip ambulances with Tc-reading thermometers, it is likely that pre-hospital services are equipped with muchless-expensive, standard medical thermometers able to measure the temperature of the body surface [5]. However, it must be strongly stressed that the temperature of the body surface, mouth, or even that of the auditory canal (especially measured with an infra-red sensor), does not reflect the core temperature [6-8]. Remarkably, 88 years ago the adequacy of temperature measurement in the oesophagus or rectum was 
already highlighted by Britton [9]. The paucity of Tcreading thermometers in European emergency medical services has been shown in studies by Freeman et al., Karlsen et al., and Henriksson et al. [10-12]. Such thermometers are still not widely available in prehospital care, even though a simple thermistor-based thermometer suitable for oesophageal or rectal use was developed by Clark and Trolander in 1954 [13].

Instead of temperature measurement, Tc estimation based on clinical signs is commonly used [14, 15]. However, the correlation between core temperature and symptoms is weak and may lead to management errors [16]. For instance, some severely cold patients may present symptoms of mild or moderate hypothermia and could be disqualified from ECLS rewarming [17]. On the other hand, unnecessary remote transports of patients to an ECLS facility may be carried out due to the underestimation of Tc when a history of cold exposure and clinical presentation are unclear and falsely suggest severe hypothermia. Some patients in hypothermic cardiac arrest must be evacuated from difficult terrain (e.g. a stairwell). This may require interruptions in manual chest compressions, which is allowed by ERC guidelines unless Tc exceeds $28^{\circ} \mathrm{C}$ [4]. However, hypothermic cardiac arrest may occur even at $\leq 32^{\circ} \mathrm{C}$ [2]. Since the oxygen requirements of the brain decrease by an average of $5 \%$ per $1^{\circ} \mathrm{C}$ drop in temperature [18], they may be too high $>30^{\circ} \mathrm{C}$ to enable survival without neurological deficit after interrupted resuscitation. One should also take into account the fact that a large proportion of patients worldwide suffer from sub-chronic and chronic so-called "urban" hypothermia. The significance of this problem will probably continue to increase in our aging society [19]. Since recognition of severe urban hypothermia based on clinical symptoms is very difficult, the only way to confirm the diagnostic suspicion is to measure core temperature.

It should be emphasised that hypothermia is the only reversible cause of prolonged cardiac arrest, which is associated with excellent neurological outcomes. The study of Pasquier et al. showed that $84 \%$ of survivors had no neurological deficit (overall survival rate 37\% - 106 out of 286 patients) [3]. Core temperature is one of crucial elements for making critical, sometimes vital decisions. Since life-saving treatment should not be delayed, the transportation of severely hypothermic patients to the nearest hospital instead of an ECLS facility just for Tc measurement is unacceptable.

Another medical emergency caused by abnormal body temperature is heat stroke. According to the ERC guidelines, diagnosis in such cases is also based on Tc measurement [4]. Because effective cooling during the first $30 \mathrm{~min}$ is essential in reducing mortality, and this treatment can be carried out in a pre-hospital setting, the patient should be diagnosed and treated as soon as possible [20]. Hence, availability of early Tc measurement is also required for ethical reasons.
The placement of an oesophageal probe is an invasive procedure and may be difficult in the pre-hospital setting, even for experienced rescuers. Hence, appropriate training programmes must precede changes of the legal basis to measure Tc by non-physician staff.

The number of patients in a state of severe hypothermia treated with ECLS in Poland has rapidly increased in the last few years. We believe this is the effect of changes in national funding regulations pertaining to ECLS, and of an increase in awareness due to our educational programme [21, 22]. Therefore, it is justified to expect a further increase in the number of saved lives due to the possibility of early Tc measurement. Although the ERC has set the path that we should follow, individual countries or regions also have to develop their own legal regulations. Nowadays, the early diagnosis of hypothermia seems to be the weakest link in the chain of survival in hypothermic cardiac arrest.

The main limitation of our study is the low response rate $(64.3 \%)$. It may reflect a lack of appreciation of the role of Tc measurement in the chain of survival among non-responders; however, it should be noted that questionnaires were sent only once through each distribution channel. On the other hand, even if nonresponders had all legal regulations to support Tc measurement in EMS (which is very unlikely), this would still only be $35.7 \%$ of all EU countries.

\section{Conclusions}

Even though the ERC has issued guidelines in which decision making strongly depends on precise Tc assessment, the Emergency Medical Services in Europe have no legal background to be equipped with suitable thermometers. Medical staff eligibility to measure Tc has not been established in the majority of countries. Hence, possibilities of following ERC guidelines in pre-hospital treatment of hypo- and hyperthermic patients may be limited. Some official regulations may help medical personnel with optimal patient management.

\section{Acknowledgments}

We would like to thank Dr. Paweł Krawczyk and the Polish Ministry of Health for their support in data collection.

\section{Conflict of interest}

The authors declare no conflict of interest.

\section{References}

1. Soar J, Nolan JP, Böttiger BW, Perkins GD, Lott C, Carli P, Pellis T, Sandroni C, Skrifvars MB, Smith GB, Sunde K, Deakin CD, Koster RW, Monsieurs KG, Nikolaou NI. European Resuscitation Council Guidelines for resuscitation 2015. Resuscitation 2015; 95: 100-147. 
2. Brown D. Hypothermia. In: Tintinalli's Emergency Medicine A Comprehensive Study Guide. $8^{\text {th }}$ ed. Tintinalli J, Stapczynski J, Ma O, Yealy D, Meckler G, Cline D (eds). McGraw-Hill Education, New York 2014; 1357-1365.

3. Pasquier M, Hugli O, Paal P, Darocha T, Blancher M, Husby P, Silfvast T, Carron P-N, Rousson V. Hypothermia outcome prediction after extracorporeal life support for hypothermic cardiac arrest patients: the HOPE score. Resuscitation 2018; 126: 58-64.

4. Truhlář A, Deakin CD, Soar J, Khalifa GEA, Alfonzo A, Bierens JJLM, Brattebø G, Brugger H, Dunning J, Hunyadi-Antičević S, Koster RW, Lockey DJ, Lott C, Paal P, Perkins GD, Sandroni C, Thies KC, Zideman DA, Nolan JP, Barelli A, Böttiger BW, Georgiou M, Handley AJ, Lindner T, Midwinter MJ, Monsieurs KG, Wetsch WA. European Resuscitation Council Guidelines for Resuscitation 2015. Section 4. Cardiac arrest in special circumstances. Resuscitation 2015; 95: 148-201.

5. Podsiadło P, Darocha T, Kosiński S, Sanak T, Gałązkowski R. Body temperature measurement in ambulance: a challenge of 21-st century? BMC Emerg Med 2019; 19: 44.

6. Skaiaa SC, Brattebø G, Aßmus J, Thomassen $\varnothing$. The impact of environmental factors in pre-hospital thermistor-based tympanic temperature measurement: a pilot field study. Scand J Trauma Resusc Emerg Med 2015; 23: 72.

7. Niven DJ, Gaudet JE, Laupland KB, Mrklas KJ, Roberts DJ Stelfox HT. Accuracy of peripheral thermometers for estimating temperature: a systematic review and meta-analysis. Ann Intern Med 2015; 163: 768-777.

8. Strapazzon G, Procter E, Paal P, Brugger H. Pre-hospital core temperature measurement in accidental and therapeutic hypothermia. High Alt Med Biol 2014; 15: 104-111.

9. Britton SW. Extreme hypothermia in various animals and in man: with notes on the detection of life and the possibility of recovery in cases of apparent death from exposure to cold. Can Med Assoc J 1930; 22: 257-261.

10. Karlsen AM, Thomassen Ø, Vikenes BH, Brattebø G. Equipment to prevent, diagnose, and treat hypothermia: a survey of Norwegian pre-hospital services. Scand J Trauma Resusc Emerg Med 2013; 21: 63.

11. Henriksson O, Björnstig U, Saveman BI, Lundgren PJ. Protection against cold - a survey of available equipment in Swedish pre-hospital services. Acta Anaesthesiol Scand 2017; 61: 1354-1360.

12. Freeman S, Deakin CD, Nelson MJ, Bootland D. Managing accidental hypothermia: a UK-wide survey of prehospital and search and rescue providers. Emerg Med J 2018; 35: 652-656.

13. Clark LC, Trolander H. Thermometer for measuring body temperature in hypothermia. J Am Med Assoc 1954; 155 : 251-252.

14. Durrer B, Brugger H, Syme D. The medical on-site treatment of hypothermia: ICAR-MEDCOM recommendation. High Alt Med Biol 2003; 4: 99-103.

15. Podsiadło P, Darocha T, Kosiński S, Sałapa K, Ziętkiewicz M, Sanak T, Turner R, Brugger H. Severe hypothermia management in mountain rescue: a survey study. High Alt Med Biol 2017; 18: 411-416.

16. Deslarzes T, Rousson V, Yersin B, Durrer B, Pasquier M. An evaluation of the Swiss staging model for hypothermia using case reports from the literature. Scand J Trauma Resusc Emerg Med 2016; 24: 16.
17. Pasquier M, Zurron N, Weith B, Turini P, Dami F, Carron P, Paal P. Deep accidental hypothermia with core temperature below $24^{\circ} \mathrm{C}$ presenting with vital signs. High Alt Med Biol 2014; 15: 58-63.

18. Mallet ML. Pathophysiology of accidental hypothermia. QJM 2002; 95: 775-785.

19. Paal P, Rauch S. Indoor accidental hypothermia in the elderly: an emerging lethal entity in the $21^{\text {st }}$ century. Emerg Med J 2018; 35: 667-668.

20. Belval LN, Casa DJ, Adams WM, Chiampas GT, Holschen JC, Hosokawa Y, Jardine J, Kane SF, Labotz M, Lemieux RS, McClaine KB, Nye NS, O’Connor FG, Prine B, Raukar NP, Smith MS, Stearns RL. Consensus statement - prehospital care of exertional heat stroke. Prehospital Emerg Care 2018; 22: 392-397.

21. Darocha T, Kosiński S, Jarosz A, Gałązkowski R, Sadowski J, Drwiła R. Severe accidental hypothermia center. Eur J Emerg Med 2015; 22: 288-291.

22. Pawłowski W, Lasota D, Goniewicz K, Goniewicz M. Effects of first aid training in emergency preparedness and response. Medical Studies 2018; 34: 259-263.

\section{Address for correspondence:}

\section{Paweł Podsiadło}

Department of Emergency Medicine

Jan Kochanowski University

al. IX Wieków Kielc 19a, Kielce, Poland

Phone: +48 413496958

E-mail: p.podsiadlo.01@gmail.com 